Nig. J. Biotech. Vol. 38 (2) : 109-117 (Dec 2021)

ISSN: 01891731

Available online at

NIGERIAN JOURNAL OF

BIOTECHNOLOGY

http://www.ajol.info/index.php/njb/index

and www.biotechsocietynigeria.org

DOI: https://dx.doi.org/10.4314/njb.v38i2.12

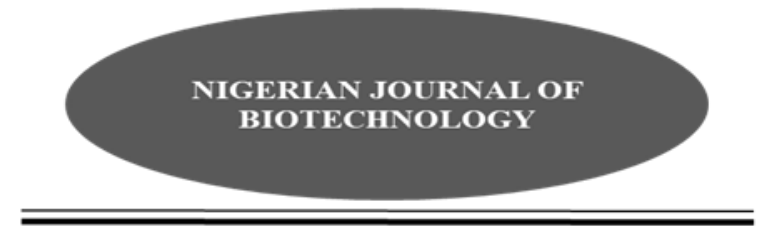

\title{
Genetic Diversity Of Andropogon Species With Different Microsatellite Markers For Better Selection And Improvement
}

\author{
${ }^{1}$ Akinyemi, B. T., ${ }^{1}$ Okukenu, 0. A., ${ }^{1}$ Dele, P. A., ${ }^{1}$ Kalenikanse, 0. B, ${ }^{2}$ Wheto, M., \\ ${ }^{2}$ Sanda, F. and ${ }^{1}$ Jolaosho, A. 0. \\ ${ }^{1}$ Department of Pasture and Range Management \\ College of Animal Science and Livestock Production \\ Federal University of Agriculture, Abeokuta, Ogun State, Nigeria. P.M.B 2240 \\ 2Department of Animal Breeding and Genetics \\ College of Animal Science and Livestock Production \\ Federal University of Agriculture, Abeokuta, Ogun State, Nigeria. P.M.B 2240
}

\begin{abstract}
Pastures have over the years been selected for important traits and their breeding has resulted in some high yielding forage grasses with great adaptive and population expansion traits. The research was carried out to study genetic diversity of nine Andropogon spp. sourced from Remo zone of Ogun State using four microsatellite markers (Phil227562, Xcup63, CTM59, and Xcup14). Genomic DNA was extracted from succulent leaf part of Andropogon grass using DNA extraction procedure of Zymo spin ${ }^{\mathrm{TM}}$ technology. Every one of the loci-populace is in with Hardy-Weinberg equilibrum. A sum of eight alleles were noticed and the quantity of alleles per locus has an estimation of 2.00, while the number of alleles ranged from 1.528 (Phil227562) to 1.946 (Xcup63). The viable number of alleles was lesser than noticed number at all the loci. The Shannon's Information Index differed among the loci with 0.530 (Phil227562) to 0.679 (Xcup63) though Inbreeding coefficient across the Andropogon grass clones was negative (mean $=-0.429$ ), going from 0.07 (Phil 227562) to 0.714 (Xcup63) with $100 \%$ polymorphic loci. The noticed heterozygosity was higher than expected heterozygosity for all markers of the grass considered.
\end{abstract}

Keyword: Andropogon grass; inbreeding; locations; Molecular markers; species.

\section{Introduction}

Grasses are generally the most utilized feed for animals in ruminant production. Comparative qualities have been carried out to evaluate the significance of grasses, and since they share a comparative supplement of qualities, similar arrangement of qualities may have been chosen (Edward et. al., 2001) leading to some other important genes being neglected. Andropogon grass belongs to the Poaceae family, and it is an important tropical grass characterised by its wide distribution in tropical and subtropical regions (Clayton and Renvoize, 1986). It has been estimated that Andropogon spp. constitutes $60 \%$ of the grass biomass in the natural vegetation of the tropical region, and greatly contributes to livestock production (Remison, 1978). Andropogon spp. is an excellent forage for both livestock and wildlife due to its palatability and high biomass which are important characteristics for selection of monocultures suitable for grassland establishment or extensive grazing practices (USDA NRSC, 2002).

The improvement of crops through biotechnological approach has begun in late 
eighties which gained surprising ground at the worldwide level. These different biotechnological instruments incorporated procedures for understanding the hereditary construction of the plants, incorporating unfamiliar qualities directly into the plant genome and in-vitro recovery of plants from any plant part (Ajoy et. al., 2009). Biotechnological approach offers openings for production of novel varieties in searches which as such are impractical through regular techniques. In grasses, the achievement accomplished so far has been restricted, however, there have been significant improvement of some the grasses examples are Lolium, Agrostis and Paspalum species (Ajoy et. al., 2009).

There are a few micro procedures that might be utilized occasionally for characterisation of germplasm, cultivar recognizable proof, recognition of crossovers and hereditary planning, quality attribute loci (QTL) ID and quality labeling. The qualities distinguished from any plant or living being can be moved to the objective species because of closeness in DNA grouping across different species and genera. Protection of hereditary assets involves a few exercises, a significant number of which may enormously profit by information produced through applying micro satellite marker advancements. This is a technique associated with identifying and securing germplasm (finding and depicting the variety), its preservation (utilizing compelling systems) and assessment for helpful attributes. In all, the accessibility of molecular genetic database guarantees adoption of better preservation techniques that will bring about improved germplasm (De Vicente et. al., 2005). Micro-satellite marker frameworks have helped with choosing alluring genotypes, to look at hereditary variety and cultivar soundness, and to be utilized for distinguishing cultivar characteristics. (Barker et. al., 2001). Accordingly, the aim of this research, was to decide the hereditary variety of Andropogon spp. using four microsatellite markers for better improvement.

Materials and Methods

\section{Sampling sites}

Fresh leaf portions of young Andropogon grasses were harvested from nine geographical locations in Remo zones of Ogun State (Table 1). $5 \mathrm{~g}$ of the leaf parts were prepared in ethanol before DNA extraction study.

Table 1: The coordinates of the Andropogon spp. collected

\begin{tabular}{|c|c|c|}
\hline & LOCATION & DEPTH \\
\hline 1 & 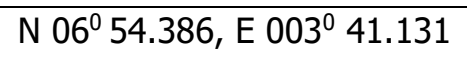 & $32 \mathrm{ft}$ \\
\hline 2 & 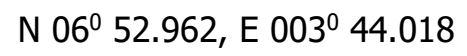 & $36 \mathrm{ft}$ \\
\hline 3 & N $06^{0} 53.091$, E $003^{0} 42.527$ & $22 \mathrm{ft}$ \\
\hline 4 & N $06^{0} 53.091$, E $003^{0} 42.533$ & $21 \mathrm{ft}$ \\
\hline 5 & N $06^{0} 52.607$, E $003^{0} 40.944$ & $25 \mathrm{ft}$ \\
\hline 6 & $\mathrm{~N} 06^{0} 52.428, \mathrm{E} 003^{0} 40.455$ & $25 \mathrm{ft}$ \\
\hline 7 & N $06^{0} 51.747$, E $003^{0} 38.664$ & $24 \mathrm{ft}$ \\
\hline 8 & 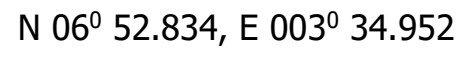 & $27 \mathrm{ft}$ \\
\hline 9 & N $06^{0} 55.557$, E $003^{0} 33.398$ & $27 \mathrm{ft}$ \\
\hline
\end{tabular}


Genomic DNA Extraction

Genomic DNA was extricated from the grasses at Laboratory of Animal Breeding and Genetics Department, College of Animal Science and Livestock Production, Federal University of Agriculture, Abeokuta, Nigeria using Zymo plant DNA extraction unit following manufacturer's protocol.

PCR amplification and gel electrophoresis

A total of four simple sequence repeat microsatellite primer pairs as shown in Table 2 were used for PCR amplification of Andropogon grass samples in $10 \mu \mathrm{l}$ reaction mixture containing 4 $\mu$ l Quick Load 2X Master Mix with Standard Buffer to which $2 \mu$ l of Nuclease-Free water and $1 \mu \mathrm{l}$ each for the forward and reverse primer and $2 \mu \mathrm{l}$ of template DNA was added. The

Table 2: Microsatellite markers used to Andropogon grass
PCR (Peltier thermal cycler Model PCR - 96G) conditions utilized were an initial denaturation of $94^{\circ} \mathrm{C}$ ( $3 \mathrm{~min}$ ) trailed by 35 cycles of $94^{\circ} \mathrm{C}$ ( 30 $\mathrm{sec})$, annealing at (1 $\mathrm{min})$, extension at $72{ }^{\circ} \mathrm{C}(2$ $\mathrm{min})$, final extension at $72{ }^{\circ} \mathrm{C}(10 \mathrm{~min})$ and hold at $4{ }^{\circ} \mathrm{C}$. The PCR products were run on $1.2 \%$ agarose gel electrophoresis stained with Ethidium Bromide in 0.5X TAE support at $90 \mathrm{~V}$ for 30 minutes and viewed on Ultra Violent transilluminator and captured in UVP DIGIDOC IT framework (FOTODYNE frameworks, USA). PCR products with clear single band (using Quick - Load Purple 50 bp DNA Ladder) enhancement on the agarose gel was excised using DNA hereditary analyzer 2010 programming (Okukenu et al., 2020)

assess genetic diversity in the samples of

\begin{tabular}{llll}
\hline Primers & $\left(\right.$ Forward 5"- $\left.-3^{\prime \prime}\right)$ & $\left(\right.$ Reverse $\left.5^{\prime \prime}-3^{\prime \prime}\right)$ & $\begin{array}{l}\text { Annealing } \\
\text { temperature }\left({ }^{\circ} \mathrm{C}\right)\end{array}$ \\
\hline $\begin{array}{l}\text { Phil227562 } \\
\text { Xcup14 }\end{array}$ & TGATAAAGCTCAGCCACAAGG & ATCTCGGCTACGGCCAGA & 56 \\
& TACATCACAGCAGGGACAGG & CTGGAAAGCCGAGCAGTATG & 53 \\
CTM59 & TCCTCGACATCCTCCA & & \\
Xcup63 & GTAAAGGGCAAGGCAACAAG & GACACCTCGTAGCACTCC & 54 \\
\hline
\end{tabular}

\section{Data analysis}

Information on gel band generated by GENEMAPPER programming v.3.7 (Applied Biosystems) were moved to Microsoft Excel and examined for different hereditary boundaries which included number of alleles per locus, heterozygosity (Ho), quality diversity (He), Shannon Information Index, and obsession list (f) utilizing GenalEX (Peakall and Smouse, 2009). Genotyping was done by using Gel Analyzer software (2010).

\section{Results}

The gel electrophoresis picture depicts the amplification of Andropogon genomic DNA samples with a selected SSR marker (Phil227562). Lane 1 (M) depicts the molecular weight marker (100 to 1000 base pair DNA ladder), while lane 1 to lane 17 shows the amplification of the DNA samples of Andropogon spp from Remo zone with primer Phil227562 (Figure 1).

Genotypic difference of microsatellite markers used for Hardy Weinberg Test

In the population of Andropogon spp. collected at Remo, the genotype $A B$ of locus Phil227562 and Xcup 63 has the highest frequency of 0.833 , for locus Xcup14 genotype $A B$ has the lowest frequency of 0.6 while the genotype $B B$ of locus CTM59 has the highest frequency (0.56), therefore the genotype $A B$ has low genetic variation in its loci which might provide adequate information on genetic selection of Andropogon spp. (Table 3)

Test for Hardy --Weinberg Equilibrium (HWE) 
Akinyemi et al. / Nig. J. Biotech. Vol. 38 Num. 2 : 109-117 (December 2021)

Each population's single locus for HWE was determined. The assumption or hypothesis was that cultivars in each population were in HWE (observed $=$ expected). In Andropogon grass of Remo population, all the four loci were tested for Hardy Weinberg's equilibrium using Chisquare analysis method, the observed heterozygosity and expected heterozygosity were not significantly different (Table 4). 
Akinyemi et al. / Nig. J. Biotech. Vol. 38 Num. 2 : 109-117 (December 2021)

$\begin{array}{llllllllllllllllll}M & 1 & 2 & 3 & 4 & 5 & 6 & 7 & 8 & 9 & 10 & 11 & 12 & 13 & 14 & 15 & 16 & 17\end{array}$

Figure 1: Gel electrophoresis picture showing amplification of DNA samples using CTM59 primer. Lane 1 (M) depicts the molecular weight marker (100 to 1000 base pair DNA ladder), while lane 1 to lane 17 shows the amplification of the DNA samples of Andropogon spp. from Remo zone with primer Phil227562

Table 3: Genotypic differences in Andropogon spp. with four (4) microsatellite markers

\begin{tabular}{lllll}
\hline Locus & Genotype & Ho & He & Frequency \\
\hline Phil227562 & 11 & 0 & 1.042 & 0.000 \\
& 12 & 4 & 2.917 & 0.833 \\
Xcup14 & 13 & 5 & 2.042 & 0.167 \\
& 11 & 0 & 0.450 & 0.000 \\
& 12 & 3 & 2.100 & 0.600 \\
CTM59 & 13 & 2 & 2.450 & 0.400 \\
& 11 & 0 & 0.444 & 0.000 \\
& 12 & 4 & 3.111 & 0.444 \\
Xcup63 & 13 & 5 & 5.444 & 0.556 \\
\hline
\end{tabular}


Akinyemi et al. / Nig. J. Biotech. Vol. 38 Num. 2 : 109-117 (December 2021)

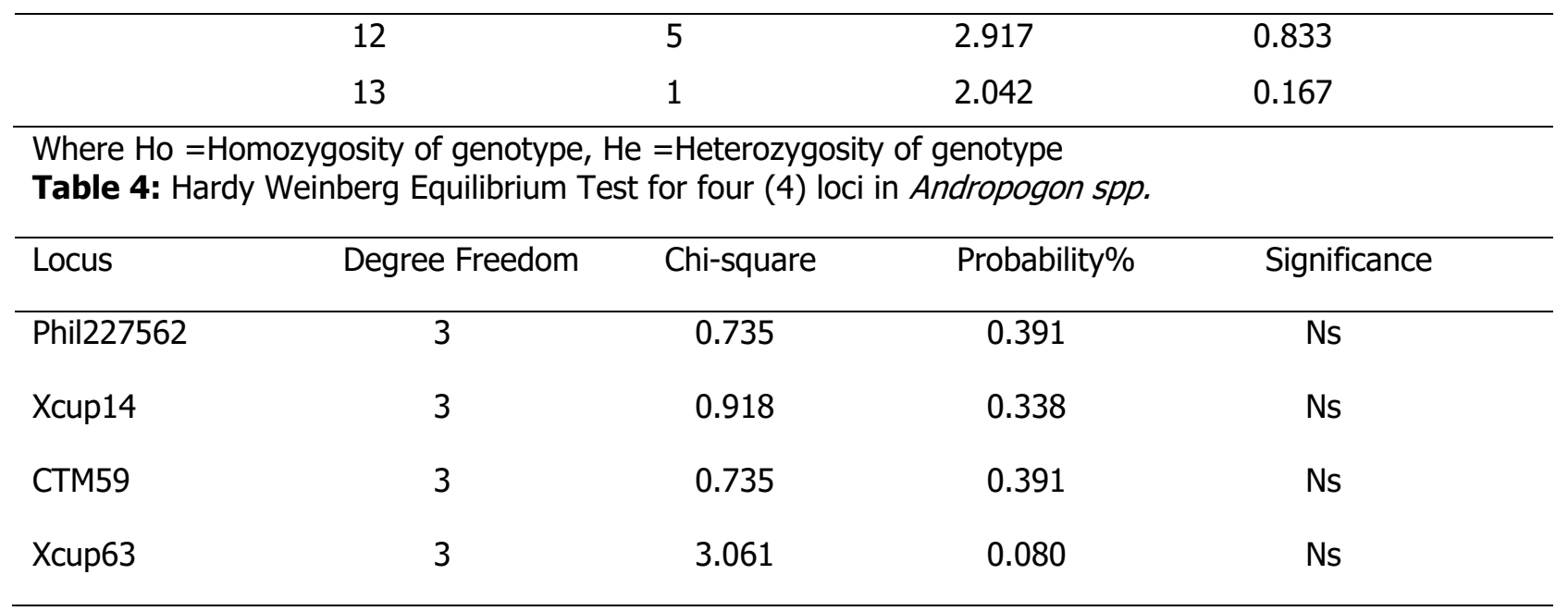

Key: Ns= Not significant

Genetic Characteristics of SSR Markers

Genetic diversity parameters assessed by the four (4) SSR markers across all the Andropogon grass populations such as allele number, effective number of alleles, Shannon's Information Index, observed and expected heterozygosity within population are presented in Table 5. Every one of the loci showed clear evidence of functionality with considerable degrees of hereditary variety ranges. A sum of eight (8) alleles were noticed and the quantity of alleles per locus was similar, with a normal estimation of 2.00, though the number of alleles shifted from 1.528 (Phil227562) to 1.946 (Xcup63) with a normal estimation of 1.682 and standard error of 0.099. The compelling number of alleles is lesser than noticed number at all the loci.

The Shannon's Information Index varies among the loci with a range of 0.530 (Phil227562) to
0.679 (Xcup63) with an average value of 0.587 and standard error of 0.036 whereas fixation index across the Andropogon grass was negative (mean $=-0.429$ ), ranging from 0.07 (Phil 227562 ) to 0.714 (Xcup63) with $100 \%$ polymorphic loci. In relation, the sample size of allele ranges from 5 (Xcup14) - 9 (Phil227562) with an average of 7.250 and standard error of 1.031 .

The noticed heterozygosity among the Andropogon grass species as shown by the 4 SSR markers were at same level over all loci, with a mean of 0.581 , ranging from 0.444 (Phil227562 and CTM59) to 0.833 (Xcup63), while the expected heterozygosity has an average mean of 0.399 , ranging from 0.366 (CTM59) to 0.530 (Xcup63). 
Akinyemi et al. / Nig. J. Biotech. Vol. 38 Num. 2 : 109-117 (December 2021)

Table 5: Genetic diversity indices of four (4) markers in Andropogon spp

\begin{tabular}{|c|c|c|c|c|c|c|c|c|c|}
\hline Locus & Alleles & frequency & $\mathrm{N}$ & $\mathrm{Na}$ & $\mathrm{Ne}$ & I & Ho & $\mathrm{He}$ & $\mathrm{F}$ \\
\hline \multirow[t]{2}{*}{ Phil227562 } & $A$ & 0.222 & 9 & 2.000 & 1.528 & 0.530 & 0.444 & 0.346 & -0.286 \\
\hline & B & 0.778 & & & & & & & \\
\hline \multirow[t]{2}{*}{ Xcup14 } & $A$ & 0.300 & 5 & 2.000 & 1.724 & 0.611 & 0.600 & 0.467 & -0.429 \\
\hline & $B$ & 0.700 & & & & & & & \\
\hline \multirow[t]{2}{*}{ CTM59 } & $A$ & 0.222 & 9 & 2.000 & 1.528 & 0.530 & 0.444 & 0.366 & -0.286 \\
\hline & B & 0.778 & & & & & & & \\
\hline \multirow[t]{2}{*}{ Xcup63 } & $A$ & 0.417 & 6 & 2.000 & 1.946 & 0.679 & 0.833 & 0.530 & -0.714 \\
\hline & $B$ & 0.583 & & & & & & & \\
\hline Mean \pm SEM & & & $7.250 \pm 1.031$ & $2.00 \pm 0.00$ & $1.682 \pm 0.099$ & $\begin{array}{l}0.587 \pm \\
0.036\end{array}$ & $0.581 \pm 0.092$ & $0.399 \pm 0.034$ & $-0.429 \pm 0.101$ \\
\hline
\end{tabular}

Where $\mathrm{N}=$ size of the alleles, $\mathrm{Na}=$ number of alleles, $\mathrm{Ne}=$ number of effective alleles, $\mathrm{I}=$ Shannon's Information Index, $\mathrm{F}=\mathrm{Fixation}$ Index. 


\section{Discussion}

Genotyping of Andropogon grass species was achieved utilizing four (4) SSR markers. All markers utilized in this investigation created a Shannon's Information list which is a proportion of hereditary changeability demonstrating the information available on the evaluated loci. Two of the markers Phil227562 and Xcup63 had relatively the same Shannon index values, suggesting similarities in their genetic information model which was in accordance with the report of Elibariki et al. (2013).

Genetic variation is fundamental to plant breeders in selecting and maintaining genetic diversity within a population. A high hereditary variety was seen among the grass species used which is ascribed to recombination as a result of heterozygosity observed in the species (Azevedo et. al., 2012). The recognition of a high number of alleles in the current research recommends an undeniable degree of variety of Andropogon spp tested within the ecological area. The current investigation was established on the reason that Andropogon grass species could isolate dependent on ecological location and consequently would offer an interesting hereditary asset for reproducing programs in the area.

The noticed heterozygosity was higher than expected heterozygosity for all markers of the grass considered, suggesting the presence of numerous similarly continuous alleles and the high hereditary changeability in the markers. This demonstrates high estimation of these hereditary assets in further and prospective conservation of the grass. As indicated by Alves et. al., (2007), the quantity of alleles is associated with the normal heterozygosity esteem. The more alleles in the populaces recommend a bigger number of heterozygosities, and this was verified by the proportions given by the Hard-Weinberg equilibrium (Griffiths et. al., 2013); the qualities found in the current investigation showed that the Andropogon population were within the Hardy-Weinberg Equilibrium, as was shown by the mean obsession list.

The mean fixation index was negative, suggesting that the population had more heterozygotes than homozygotes. This may be due to the more densely populated species in the area under study, as the landscape is less susceptible to agriculture and grazing activities. Clustered plant populaces may show decreased inbreeding rates because of the lower likelihood of self-pollination (Carvalho et. al., 2010). As indicated by Gaino et. al. (2010), grouped plant populaces tend towards increment in their variety and size. The high hereditary variety within the types of Andropogon in the current examination authenticates what is normal from tropical grasses with high population development rate.

\section{References}

Ajoy, K. R., Singh K.A., Devendra, M.R. (2009). Hand Book of Agriculture, Chapter: Forage crops and grasses, Publisher: The Indian Council of Agricultural Research (ICAR), New Delhi, 13531417pp.

Alves, R.M, Sebbenn, A.M, Artero, A.S and Clement C. (2007). High levels of genetic divergence and inbreeding in populations of cupuassu (Theobroma grandiflorum). Tree Gene. Genomes. 3: 289-298.

Azevedo, A.L.S., Costa, P.P., Machado, J.C., Machando, M.A., Pereira, A.V. and Ledo. F.J.S. (2012). Cross species amplification of Pennisetum glaucum microsatellite markers in Pennisetum purpureum and genetic diversity of Napier grass accessions. Crop Sci. 4: 17761785.66

Barker, J.S.F., Tan, S.G., Moore, S.S., Mukherjee, T.K., Matheson, J.L. and Selvaraj, O.S. (2001). Genetic variation within and relationships among populations of Asian goats (Capra hircus). J. of Ani. Breeding Gen. 118: 213-223.

Carvalho, A.C.M.D, Freitas, M.L.M, Moraes, S.M.B.D and Moraes, M.L.T.D, (2010). Diversidade genética, endogamiae fluxo gênico em pequena população fragmentada de Copaifera langsdorffii. Revista Brasileira de Botanica 33: 599-606. 
Clayton, W. D. and Renvoize, S. A. (1986). Genera graminum: grasses of the world. London: Her Magesty's Stationery Office.

de Vicente MC, Guzmán FA, Engels J, Rao VR (2005) Genetic characterization and its use in decision making for the conservation of crop germplasm. The role of biotechnology. In: International workshop the role of biotechnology for the characterization and conservation of crop, forestry, animal and fishery genetic resources. FAO, Fobiotech, Ecogene, Siga, Turin, pp 121-128, 5-7 March 2005

Edward, S. B., Jeffrey, M.T. and Stephen K. (2001). Molecular diversity, structural domestication of grasses, United States Department of Agriculture (USDA)- The Agricultural Research Service (ARS), Plant Science Research Unit Dept. of Genetics, North Carolina State University, Raleigh, NC 279657614 Institute for Genomic Diversity, Cornell University, Ithaca, NY 14853-2703, Gene. Res., Cambridge 77: 213 -218.

Elibariki, G., Njahira, M., Wanjala, B., Hosea, K., and Ndunguru, J. (2013). Genetic diversity and identification of duplicates in selected Tanzanian farmer preferred cassava landraces using simple sequence repeat (SSR) markers. Inter. J. of Rsch. in Plt. Sci. 3(4): 81-87

Gaino, A.P., Silva, A.M., Moraes, M.A. and Alves, P.F. (2010). Understanding the effects of isolation on seed and pollen flow, spatial genetic structure and effective population size of the dioecious tropical tree species Myracrodruon urundeuva. Conser. Gene. 11: 1631-43.

Griffiths, A.J.F., Lewontin, R.C., Carroll, S.B. and Wessler, S.R. (2013). Introdução à Genética. 10st edn. Guanabara Koogan, Rio de Janeiro.

Kawube, G., Alicai, T., Wanjala, B., Njahira, M., Awalla, J. and Skilton, R. (2015). Genetic diversity in napier grass (Pennisetum purpureum) assessed by SSS markers. J. of Agric. Sci. 7 (7) 147-155.

Okukenu, O. A., Olajide, A. A., Dele, P. A., Wheto, M., Akinyemi, B. T., Jolaosho, A. O., Jokosenumi, B. O. and Shonde, T. J. 2020. Microsatellite markers-based characterisation of elephant grass (Pennisetum purpureum) harvested from selected locations in South-West Nigeria. Nig. J. of Biotech 37 (1): 38-45.

Peakall, R. and Smouse, P. E. (2009). GENALEX 6: Genetic Analysis in Excel. Population genetic software for teaching and research. Mole. Ecology Notes 6:288-295.

Remison, S. U. (1978). Evaluation of some pasture species in the Southern Guinea savanna zone of Nigeria. Research Bulletin No. 5. National Cereals Research Institute. Ibadan, 8pp.

United States Department of Agriculture (USDA), National Resource Conservation Service (NRCS) (2002). Plant Fact Sheet on Andropogon gerardii vitman 